\title{
Herpes Simplex Virus Type 2: Bystander or Active Player in Cervical Carcinogenesis?
}

\author{
Jude Ogechukwu Okoye* \\ Department of Medical Laboratory Science, Babcock University, Nigeria
}

Submission: September 19, 2018 ; Published: October 05, 2018

*Corresponding author: Jude Ogechukwu Okoye, Department of Medical Laboratory Science, Babcock University, Nigeria, Tel: +2347031119994; Email: okoyej@babcock.edu.ng/judeogeokoye@gmail.com

\begin{abstract}
More emphasis have been placed on producing vaccines that prevent host cell entry by Human Papillomavirus (HPV) while less attention has been given to Herpes Simplex virus type 2 (HSV-2) which potentially promotes acquisition and co-habitation of human immunodeficiency virus (HIV), HPV and Epstein-Barr virus (EBV). The tendency for HSV-2 to induce ulcerations and chronic inflammation following reactivation, and its potential to up-modulate both HPV regulatory and oncogenic gene and downregulate host tumour suppressor suggest that it is not a bystander in cervical carcinogenesis. Thus, efforts geared towards finding HSV-2 effective microbicide and vaccine should be intensified so as to reduce cervical cancer related mortality.
\end{abstract}

Keywords: Herpes Simplex virus type 2; Human papillomavirus; Epstein-Barr virus; Cervical cancer

Abbreviations: HPV: Human Papillomavirus; HIV: Human Immune virus; SSC: Squamous Cell Carcinoma; LMP1: Latent Membrane Protein 1; EBV: Epstein-Barr virus; CIN: Cervical Intraepithelial Neoplasia

\section{Introduction}

Cervical cancer is the second most common type of cancer (9.8\%) affecting women worldwide [1-3]. It commonly starts as cervical intraepithelial neoplasia progresses over as many as 10 or more years to invasive cervical carcinoma. Since about $93 \%$ of all cervical cancers contain human papillomavirus (HPV) DNA, it is believed to be the main cause of the disease [4,5]. However, contrasting reports have been made on the involvement of other viruses. One of the fingered controversial viruses is the HSV-2.

\section{Implication of HSV-2 Infection}

An epidemiological study revealed that most people are infected with the HSV-2 by the time they are 10 years old [6]. Globally, serological prevalence of HSV-2 infection ranges from 7 to $30 \%$ of the population [7]. The virus increases the risk of HIV acquisition by 5 times [8]. This increased risk of HIV acquisition by HSV-2 is thought to be caused by breaks in the protective epithelial layer, inflammation and recruitment of activated $\mathrm{CD} 4^{+} \mathrm{T}$ cells to the ulcerated site, which are target cells for HIV. HIV in turn increases cancer risk [8] by facilitating the entry, persistence, replication and reactivation of latent oncoviruses due to the expression of its transactivator protein and gp120 [9]. As a result, people infected with HIV are at least 5 times more likely to be diagnosed with cervical cancer [10]. HSV-2 infection does not only favour HIV entry but it also promotes the invasion of other oncogenic viruses. The persistence of HSV-2 and its tendency to reactivate following latency increases the number of chronic inflammation in a woman's lifetime and may also facilitate EBV infection, a potential oncogenic virus [11]. Hence, it is not surprising that cervical cancer specimens are 5.1 times more positive for HSV2 compared with cervical specimens from healthy controls [12]. After evaluating 210 cases of cervicitis and 24 cases of squamous cell carcinoma (SCC), Zhao et al. [13] reported that HSV-2 infection is 4.9 and 4.7 times more likely to be associated with cervicitis and SCC, respectively. The connection between chronic cervicitis and cervical malignancy is not farfetched. Circulating reactive oxygen species and inflammatory cytokines from activated inflammatory lymphocytes are capable of promoting DNA damage and genomic instability in proximal epithelial cells. These epithelial cells become susceptible to latent membrane protein 1 (LMP1) positive EBV with concomitant clonal proliferation and survival of EBVinfected premalignant cells following the activation of NF- $\kappa B$ and STAT3 signaling pathways [14].

\section{Epstein-Barr Virus Infection}

Epstein-Barr virus (EBV) belongs to the group of gammaherpes viruses and is responsible for epithelial malignancies including B-cell lymphomas, lymphoproliferative disorders, nasopharyngeal, gastric and salivary gland carcinomas, breast, prostate and oral cancers. It is commonly transmitted through oral secretions. Previous studies demonstrated EBV DNA in cervicitis, precancerous (cervical intraepithelial neoplasia, CIN) and 
invasive cervical carcinoma cells [15]. The level of premalignant or malignant transformation cervical epithelial cells is dependent on EBV load and lesion grade [16]. Some reports revealed higher EBV DNA positivity in CIN3 lesions (15-70\%) when compared with cervical carcinoma (5.8\%) [17-19]. Despite the low presence of EBV DNA in SCC, SCC is 2 times more likely to be EBV positive than normal cervical samples [12,15]. Additionally, a recent meta-analysis by de Lima et al. shows that EBV infection posed a twofold increased risk of precancerous cervical lesions and fourfold increased risk of cervical cancer in HPV positive women [16]. This risk is explained by the findings of some studies which revealed that EBV infection in the cervix accelerates integration of HPV genome into cervical cell's genome, enhancing genomic instability of the infected cervical cells $[16,20]$ and in some cases results in lymphoepithelioma-like (non-keratinizing) carcinoma of the cervix [15]. These reports convincingly suggest that EBV plays a direct role in cervical carcinogenesis.

\section{EBV and HSV-2 Co-Infection}

The higher prevalence of EBV+HSV-2 co-infection when compared with HPV+HSV-2 co-infection observed in recent studies suggest a higher odds for the former than the latter among women with abnormal Pap smears $[21,22]$. Elsheikh and colleagues reported a $10 \%$ and $2.4 \%$ prevalence of HPV+HSV-2 and $\mathrm{EBV}+\mathrm{HPV}$ co-infections in cervical cancer cases, respectively [12]. The low prevalence of EBV+HPV co-infection (in HSV-2 negative women) in their study when compared with previous studies $[11,19]$ suggests that the higher association between EBV and HPV observed by previous studies may have been favored by HSV-2 infection. Unfortunately, these previous early studies failed to investigate HSV-2 infection among their recruits. The fact that a recent study showed that $\mathrm{EBV}+\mathrm{HPV}+\mathrm{HSV}-2$ tri-infection is associated with higher frequency of cervical abnormalities among sex workers suggest that HSV-2 promotes EBV+HPV co-infection. Interestingly, some oncogenic HSV-2 miRNAs have been identified, among which miR-H25 has been found to exert its effects by down-modulating host miR-143, a tumour suppressor [23]. This in turn ensures immuno-escape of EBV bearing miR-BART7 with resultant tumour immortalization and resistance to cisplatin [24]. The hypermethylation, p16/CDKN2A inactivation, mutation of PIK3CA, and frequent upregulation of JAK2, PDL-1 and PDL2 observed EBV infected cells further exposes the oncogenic potential of the virus $[25,26]$.

\section{HPV and HSV-2 Co-Infection}

Evidence emanating from numerous studies suggest significant association between HSV-2 and HPV in invasive cervical cancer [27-29]. Interestingly, Zhao et al. reported that $\mathrm{HPV}+\mathrm{HSV}-2$ co-infection is 34.2 and 61.1 times more likely to be linked with CIN and SCC, respectively [30]. Paba and colleagues went further to demonstrate HPV+HSV-2 co-infection in $23.5 \%$ of cervical cancer specimens using PCR based DNA identification [30]. This underscores the importance of HSV-2 infection in HPV related cervical carcinogenesis. In line with this assertion, in vitro assay carried out by Tran-Thanh and colleagues revealed that herpes simplex virus type $2 \mathrm{Bgl}$ IIN transforms epithelial cells with concomitant overexpression of Survivin in CIN [31]. However, in vivo investigation carried out by the same team did not reveal any association between the virus and cervical cancer [31]. There appears to be a synergy between HSV-2 and HPV oncogenicity. Real-time-PCR assay revealed that HSV-2 infection increases the level of transcription of HPV E1, E2 and E6 genes, especially that of HPV 18, up to 3-fold in Caski cells and Hela cells [32-34]. This suggests that HSV-2 infection could increase the risk of cervical cancer by stimulating the overexpression of both HPV regulatory and oncogenic genes. This induces the malignant transformation of HPV -immortalised cervical keratinocytes [35].

\section{Conclusion}

Since, evidence emanating from recent studies overwhelmingly suggest that HSV-2 actively contributes to cervical carcinogenesis, efforts geared toward finding effective microbicides and vaccines should be intensified so as to reduce cervical cancer related mortality.

\section{References}

1. Apostolidou S, Hadwin R, Burnell M, Jones A, Baff D, et al. (2009) DNA methylation analysis in liquid-based cytology for cervical cancer screening. Int J Cancer 125(12): 2995-3002.

2. Jemal A, Bray F, Center MM, Ferlay J, Ward E, et al. (2011) Global cancer statistics. CA Cancer J Clin 61(2): 69-90.

3. Pedroza-Torres A, López-Urrutia E, García-Castillo V, Jacobo-Herrera N, Herrera LA, et al. (2014) MicroRNAs in Cervical Cancer: Evidences for a miRNA Profile Deregulated by HPV and Its Impact on Radio-Resistance. Molecules 19(5): 6263-6281

4. Franco EL, Rohan TE, Villa LL (1999) Epidemologic evidence and human papilloma virus infection as a necessary cause of cervical cancer. J Natl Cancer Inst 91(6): 506-511.

5. Bosch FX, Lorinz A, Munoz N, Meijer CJ, Shah KV, et al. (2002) The causal relation between human papillomavirus and cervical cancer. J Clin Pathol 55(4): 244-265.

6. Xu F, Sternberg MR, Kottiri BJ, McQuillan GM, Lee FK, et al. (2006) Trends in herpes simplex virus type 1 and type 2 seroprevalence in the United State. JAMA 296(8): 964-973.

7. Looker KJ, Garnett GP, Schmid GP (2008) An estimate of the global prevalence and incidence of herpes simplex virus type 2 infection. Bull World Health Organ 86(10): 805-812.

8. Sinayobye JA, Sklar M, Hoover DR, Shi Q, Dusingize JC, et al. (2014) Prevalence and risk factor for High-Risk Human Papilloma virus (hrHPV) infection among HIV-infected and Uninfected Rwandan women: implications for hrHPV-based screening in Rwanda. Infect Agent Cancer 9: 40.

9. Yang F, Liu Q, Hu CM (2015) Epstein-Barr virus-encoded LMP1 increases miR-155 expression, which promotes radio resistance of nasopharyngeal carcinoma via suppressing UBQLN1. Eur Rev Med Pharmacol Sci 19(23): 4507-4515.

10. Grulich AE, Leeuwen VMT, Falster MO, Vajdic CM (2007) Incidence of cancers in people with HIV/AIDS compared with immunosuppressed transplant recipients: a meta-analysis. Lancet 370(9581): 59-67.

11. Shi Y, Peng SL, Yang LF, Chen X, Tao YG, et al. (2016) Co-infection of Epstein-Barr virus and human papillomavirus in human tumorigenesis. Chin J Cancer 35:16. 
12. Elsheikh MA, Yousif IB, Osman MI, Alobaid AEA, Abdelbadie A, et al (2018) Herpes Simplex Virus type 2, Epstein Barr Virus and Human Papilloma Virus Co-infection in Cervical Squamous Cell Carcinoma among Sudanese Females. Int J Curr Res Med Sci 4(2): 93-103.

13. Zhao Y, Cao X, Zheng Y, Tang J, Cai W, et al. (2012) Relationship between cervical disease and infection with human papillomavirus types 16 and 18, and herpes simplex virus 1 and 2. J Med Virol 84(12): 1920-1927.

14. Looker KJ, Elmes JAR, Gottlieb SL, Schiffer JT, Vickerman P, Turner KME et al. (2017) Effect of HSV-2 infection on subsequent HIV acquisition: an updated systematic review and meta-analysis. Lancet Infect Dis 7(12): 1303-1316.

15. Vranic S, Cyprian FS, Akhtar S, Moustafa AIA-E (2018) The Role of Epstein-Barr Virus in Cervical Cancer: A Brief Update. Front Oncol 8: 113

16. Lima DMAP, Neto PJN, Lima LPM, Goncalves JJ, Teixeira JAG, et al. (2017) Association between Epstein-Barr virus (EBV) and cervi cal carcinoma: a meta-analysis. Gynecol Oncol 148(2): 317-328.

17. Szkaradkiewicz A, Wal M, Kuch A, Pieta P (2004) Human papillomavirus (HPV) and Epstein-Barr virus (EBV) cervical infections in women with normal and abnormal cytology. Pol J Microbiol 53(2): 95-99.

18. Seo SS, Kim WH, Song YS, Kim SH, Kim JW, et al. (2005) Epstein-Barr virus plays little role in cervical carcinogenesis in Korean women. Int J Gynecol Cancer 15(2): 312-318.

19. Khenchouche A, Sadouki N, Boudriche A, Houali K, Graba A, et al (2013) Human papillomavirus and Epstein-Barr virus co-infection in cervical carcinoma in Algerian women. Virol J 10: 340.

20. Kahla S, Oueslati S, Achour M, Kochbati L, Chanoufi MB, et al. (2012) Correlation between EBV co-infection and HPV16 genome integrity in Tunisian cervical cancer patients. Braz J Microbiol 43(2): 744-753.

21. Okoye JO, Erinle C, Ngokere AA, Jimoh A (2018a) Low CD4 cells and viral co-infection increase the risk of VaIN: Use of SCCA1 and Ki67 as diagno-prognostic biomarkers. Pathophysiology 25(1): 51-56.

22. Okoye JO, Ngokere AA, Erinle CA (2018b) Screening for cervical abnormalities associated with EBV, HPV and HSV-2 infections in SouthWest Nigeria: A tale between Sex and non-sex workers. J Oncol Sci 4(2): 85-95.

23. Pandya D, Mariani M, McHugh M, Andreoli M, Sieber S, et al. (2014) Herpes Virus MicroRNA Expression and Significance in Serous Ovarian Cancer. PLoS ONE 9(12): e114750.
24. Chen B, Li H, Zeng X, Yang P, Liu X, et al. (2012) Roles of microRNA on cancer cell metabolism. J Transl Med 10: 228.

25. Wang K, Yuen ST, Xu J, Lee SP, Yan HH, et al. (2014) Whole-genome sequencing and comprehensive molecular profiling identify new driver mutations in gastric cancer. Nat Genet 46(6): 573-582.

26. The Cancer Genome Atlas Research Network (2014) Comprehensive molecular characterization of gastric adenocarcinoma. Nature 513(7517): 202-209.

27. Thomas DB, Qin Q, Kuypers J, Kiviat N, Ashley RL, et al. (2001) Human papillomaviruses and cervical cancer in Bangkok. II. Risk factors for in situ and in vasivesquamous cell cervical carcinoma. Am J Epidemiol 153(8): 723-731.

28. Smith JS, Herrero R, Bosetti C, Munoz N, Bosch FX, et al. (2002) Herpes simplex virus- 2 as a human papillomavirus cofactor in the etiology of invasive cervical cancer. J Natl Cancer lnst 94(21): 1604-1613.

29. Garbuglia AR, Lezzi T, Capobianchi MR, Pignoloni P, Pulsoni A, et al. (2003) Detection of TT virus in lymph node biopsies of B-ce1llymphoma and Hodgkin's disease, and its association with EBV infection. Int J Immunopathol Pharmacal 16(2): 109-118.

30. Paba P, Bonifacio D, Bonito DL, Ombres D, Favalli C, et al. (2008) CoExpression of HSV2 and Chlamydia trachomatis in HPV-Positive Cervical Cancer and Cervical Intraepithelial Neoplasia Lesions Is Associated with Aberrations in Key Intracellular Pathways". Intervirol 51(4): 230-234

31. Tran-Thanh D, Provencher DM, Koushik A (2003) Herpes Simplex Virus Type II (HSV-2) is not a Cofactor to Human Papillomavirus in Cancer of the Uterine Cervix. Am J Obstet Gynecol 188(1): 129-134.

32. Hara Y, Kimoto T, Okuno Y, Minekawa Y (1997) Effect of herpes simplex virus on the DNA of human papillomavirus 18. J Med Virol 53(1): 4-12.

33. Pisani S, Fioriti D, Conte MP, Chiarini F, Seganti L, et al. (2002) Involvement of herpes simplex virus type 2 in modulation of gene expression of human papillomavirus type 18. Int J lmmunopathol. Pharmacal 15(1): 59-63.

34. Pisani S, Imperi M, Seganti L, Supertp F, Tinarp A, et al. (2004) Effect of Hsv-2 Infection on the Expression of Hpv 16 Genes in Caski Cells. Int J Immunopathol Pharmacol 17(1): 65-70.

35. Paolo DJA, Woodworth CD, Coutlee F, Zimonic DB, Bryant J, et al. (1998) Relationship of stable integration of herpes simplex virus-2 Bgl II N sub fragment Xh 02 to malignant transformation of human papillomavirusimmortalized cervical keratinocytes. Int J Cancer 76(6): 865-871.

\section{Your next submission with Juniper Publishers} will reach you the below assets

- Quality Editorial service

- Swift Peer Review

- Reprints availability

- E-prints Service

- Manuscript Podcast for convenient understanding

- Global attainment for your research

- Manuscript accessibility in different formats ( Pdf, E-pub, Full Text, Audio)

- Unceasing customer service

Track the below URL for one-step submission https://juniperpublishers.com/online-submission.php 